\title{
MORPHOMETRIC STUDY OF SPLEEN
}

\author{
Donapudi Anusha1 , D. Madhavi², Kondepudi Srinidhi' ${ }^{3}$ B. Bhagya Lakshmi ${ }^{4}$
}

${ }_{1}^{1}$ Assistant Professor, Department of Anatomy, Dr. Pinnamaneni Siddhartha Institute of Medical Sciences and Research Foundation, Chinnaoutpalli, Andhra Pradesh, India.

${ }_{2}^{2}$ Associate Professor, Department of Anatomy, Guntur Medical College, Guntur, Andhra Pradesh, India.

${ }^{3}$ House Surgeon, Department of Anatomy, NRI Medical College, Chinnakakani, Guntur, Andhra Pradesh, India.

${ }^{4}$ Retired Professor and HOD, Department of Anatomy, Dr. PSIMS and RF, Vijayawada, Andhra Pradesh, India.

\section{BACKGROUND}

ABSTRACT

Spleen is the largest lymphoid organ playing a vital role in the defense mechanism of the body and performs a unique function of filtration of blood by phagocytes. We wanted to study the morphological variations and to compare the results with previous findings and to unearth the so far unnoticed features of the spleen.

\section{METHODS}

This is a descriptive study. 60 human cadaveric normal spleens were studied. The morphological features of the spleen such as shape, surfaces, poles, and measurements of borders, weight, thickness, notches, fissures, lobes, lobules, hilum and accessory spleens have been studied.

\section{RESULTS}

Spleens showed many shapes and they were classified into 15 forms. Most of the spleens were wedge shaped [31.66\%, ], followed by triangular [11.6\%], rounded [10\%], tetrahedral [8.3\%], irregular [8.3\%], oval [5\%], bilobed [5\%], trilobed [5\%], heart shaped [3.3\%], cone shaped [1.6\%], tent shaped [1.6\%], orange peel [1.6\%], foot shaped [1.6\%], fork shaped [1.6\%] and lobulated [3.3\%]. Length, breadth, thickness and weight, varied between $6 \mathrm{~cm}-15 \mathrm{~cm}, 4.5 \mathrm{~cm}-11.5 \mathrm{~cm}, 1.5 \mathrm{~cm}-3.5 \mathrm{~cm}$ and $70-180$ grams respectively. Medial and lateral ends, surfaces, borders, notches, lobes and lobules and fissures were noted in most of the spleens. In circular, irregular conical, tent shaped spleens, the borders could not be identified properly. $96.6 \%$ of spleens showed notches on their superior border. $3.4 \%$ of spleens were without notches. Notches were absolutely absent in inferior border. Fissures were noticed on both the surfaces in $11.6 \%$ of spleens. Two accessory spleens were noticed out of 60 spleens. One accessory spleen was found near the hilum. It was pea shaped and pea sized. Another accessory spleen was oval in shape situated on a deep depression on the visceral surface of the spleen connected to it by a bridge of splenic tissue and supplied by small branches of splenic artery. It measured about $3 \mathrm{cms}$. in diameter.

\section{CONCLUSIONS}

The knowledge of different shapes of the spleen, variations in dimensions, absence/presence of notches in unusual sites, occasional presence of fissures on the surfaces, lobes and lobules and presence/absence of accessory spleens is important for physicians, surgeons, radiologists and anatomists.

HOW TO CITE THIS ARTICLE: Anusha D, Madhavi D, Srinidhi K, et al. Morphometric study of spleen. J. Evolution Med. Dent. Sci. 2019;8(18):1469-1473, DOI: 10.14260/jemds/2019/327

\section{BACKGROUND}

Spleen is a large haemolymphoid encapsulated organ belonging to reticuloendothelial system. It is termed as a haemolymph node. Spleen has no afferent Lymph vessels. Before birth it is haemopoietic, but after birth it produces monocytes, B \& T lymphocytes and thus plays an essential role in immune mechanism. People with splenectomy have a risk of over whelming post splenectomy infection (OPSI) mostly in children and a risk of septicaemia in adults. [1,2,3]

So now a days in cases of splenic injury complete splenectomy is avoided and partial splenectomy is done.

'Financial or Other Competing Interest': None.

Submission 15-03-2019, Peer Review 18-04-2019,

Acceptance 26-04-2019, Published 06-05-2019.

Corresponding Author:

Dr. D. Madhavi,

Associate Professor,

Department of Anatomy,

Guntur Medical College,

Guntur,

Andhra Pradesh, India.

E-mail: madhavikondepudi@gmail.com

DOI: $10.14260 /$ jemds/2019/327

\section{(c) (i) $(9)$}

J. Evolution Med. Dent. Sci./eISSN- 2278-4802, pISSN- 2278-4748/ Vol. 8/ Issue 18/ May 06, 2019
Other important functions of spleen are, it acts as a reservoir of blood, stores RBC \&platelets, filters blood by phagocytosis and destroys worn out erythrocytes. Splenomegaly is an important basic diagnostic indication to the existence of an underlying disorder. ${ }^{[4]}$ Although spleen shows a wide range of variations in the measurements, the spleen with more than $15 \mathrm{~cm}$ in length and extends anterior to mid axillary line and contact with the liver is considered abnormal. Clinically in most of the cases the spleen is not palpable unless it is increased to 2 to 3 times of its normal size. There are no enough studies in humans regarding the exact amount of splenic tissue required for immune function. Below a critical mass of $25 \%$ of splenic tissue, a normal immune response could not occur in most animal and some human studies.

The spleen is situated in the left hypochondrium and epigastrium between fundus of stomach and diaphragm. It is usually $12 \mathrm{~cm}$ long, $7 \mathrm{~cm}$ broad and $3 \mathrm{~cm}$ thick and its weight varies from 80 to $150 \mathrm{gms}$. The shape of the spleen varies from a slightly curved wedge to a domed tetrahedron. The shape is mostly determined by its relations to neighbouring 
structures during development. The spleen has diaphragmatic and visceral surfaces, the superior and inferior borders and anterior (Lateral) and posterior (Medial) ends or poles. The superior and inferior borders separate the two surfaces. The superior border presents 1 or 3 notches near its lateral end. The notches indicate the developmental importance that the spleen develops from fusion of separate masses of mesenchymal cells. [5]

The spleen is lobulated in the foetus due to fusion of masses of mesenchymal cells, but the lobules normally disappear before birth. The notches in the superior border of the adult spleen are remnants of the grooves that separated the lobules.[6] True anomalies of the spleen are rare except for the occurrence of accessory spleens. ${ }^{[7]}$ There are no notches in the spleen of rodents. It is rare for any human spleen to be unnotched. ${ }^{[8]}$

Varga et al 2009 studied the congenital anomalies of spleen like lobular spleen, accessory spleen, ectopic spleen, wandering spleen, polysplenia, asplenia and splenogonadal fusion.[9] Wandering spleen is due to increase in length of ligaments.

Accessory spleens or splenunculi are the additional collections of the fully functional splenic tissue that may exist near the spleen, especially in the gastrosplenic ligament or in the greater omentum. The accessory spleens are usually isolated but can be connected to the spleen by thin bands of similar tissue.[5]

\section{METHODS}

This Descriptive study was conducted on 60 Cadaveric Spleens (55 Males and 5 Females) during routine dissections for the medical students in Dr. PSIMS \& RF, Chinnaoutpalli, Vijayawada, Krishna District. After opening the peritoneal cavity, the celiac trunk, the origin, course, branches and other aspects of splenic artery were observed. The area was searched for accessory spleen if any. The spleens were taken out of the body, washed, tagged, and kept in 10\% formalin. Its shape, surfaces, ends, hilum, borders, notches, fissures, lobes and lobules were observed. Measurements like length, breadth and thickness were noted using sliding calipers and measuring tape. The weight was measured by using digital weighing machine. Variations were observed and photographed

\section{Measurements}

The length was measured between the ends along the diaphragmatic surface of the spleen; breadth was measured between upper and lower borders of spleen along a plane perpendicular to the length; the thickness of the spleen was taken with the help of sliding calipers at the maximum antero-posterior dimension of the spleen. ${ }^{[10]}$

\section{RESULTS}

In the morphological study 60 spleens were observed. The shape of the spleen varied drastically and therefore an attempt was made to classify them under 15 different forms as shown in table no-1.

\begin{tabular}{|c|c|c|c|}
\hline $\begin{array}{l}\text { Sl. } \\
\text { No. }\end{array}$ & $\begin{array}{c}\text { Shape of the Spleen } \& \\
\text { Figure Number }\end{array}$ & $\begin{array}{c}\text { Number of } \\
\text { Spleens }\end{array}$ & \begin{tabular}{|c|} 
Percentage of \\
Occurrence
\end{tabular} \\
\hline 1 & Wedge shaped & 19 & $31.66 \%$ \\
\hline 2 & Triangular & 7 & $11.6 \%$ \\
\hline 3 & Round & 6 & $10 \%$ \\
\hline 4 & Tetrahedral & 5 & $8.3 \%$ \\
\hline 5 & Irregular & 5 & $8.3 \%$ \\
\hline 6 & Oval & 3 & $5 \%$ \\
\hline 7 & Bilobed & 3 & $5 \%$ \\
\hline 8 & Trilobed & 3 & $5 \%$ \\
\hline 9 & Heart shaped & 2 & $3.3 \%$ \\
\hline 10 & Cone shaped & 1 & $1.6 \%$ \\
\hline 11 & Tent shaped & 1 & $1.6 \%$ \\
\hline 12 & Orange peel appearance & 1 & $1.6 \%$ \\
\hline 13 & $\begin{array}{c}\text { Foot shaped (with some } \\
\text { toes) }\end{array}$ & 1 & $1.6^{\wedge}$ \\
\hline 14 & Fork shaped & 1 & $1.6 \%$ \\
\hline 15 & Lobulated & 2 & $3.3 \%$ \\
\hline
\end{tabular}

Table 1. Various Shapes of Spleens in The Present Study

The parameters like length, breadth, thickness and weight were shown in table no 2 .

\begin{tabular}{|c|c|c|c|c|}
\hline $\begin{array}{c}\text { Sl. } \\
\text { No. }\end{array}$ & & Minimum & Maximum & Average \\
\hline 1 & Length & $6 \mathrm{~cm}$ & $15 \mathrm{~cm}$ & $9.82 \mathrm{~cm}$ \\
\hline 2 & Breadth & $4.5 \mathrm{~cm}$ & $11.5 \mathrm{~cm}$ & $8.24 \mathrm{~cm}$ \\
\hline 3 & Thickness & $1.5 \mathrm{~cm}$ & $3.5 \mathrm{~cm}$ & $2.85 \mathrm{~cm}$ \\
\hline 4 & Weight & $70 \mathrm{gm}$ & $180 \mathrm{gm}$ & $131 \mathrm{gm}$ \\
\hline \multicolumn{5}{|c|}{ Table 2. Parameters of Spleen in The Present Study } \\
\hline
\end{tabular}

Notches were found in 58 spleens out of 60 (96.6\%). Notches were absent in $3.4 \%$ of spleens. The number of notches varied from 0 to 3 . Among the $96.6 \%$ of spleens, notches were found only on the superior border, no notches were found on the inferior border. Single notch on the superior border was found in $86.6 \%, 2$ notches in $7 \%, 3$ notches in $3 \%$.

Among 60 spleens two accessory spleens (3.33\%) were noticed. One accessory spleen is pea shaped \& pea sized, situated close to the hilum and measured $1 \mathrm{~cm}$ in diameter. Another accessory spleen was large, oval, measures $3 \mathrm{~cm}$ in diameter and was present on the visceral surface of the main spleen connected by a bridge of splenic tissue. It was supplied by a small branch of splenic artery.

Out of 60 spleens fissures were found on the diaphragmatic surface in $6.6 \%$ and on visceral surface in $5 \%$ of specimens. Bilobed and trilobed spleens may be due to the presence of deep fissures/Notches.

\section{DISCUSSION}

The spleen is quite vital for maintaining body defense mechanism and for filtration of blood by phagocytes. The shape of the spleen was mostly determined by its neighboring relations during development. In the present study of morphology of spleens, many variations were noticed against the findings of previous authors. Regarding the shape of spleens, we noticed the variability in the shapes of the spleen and 15 different forms were noticed out of 60 spleens. These many forms were not reported by any of the previous authors.

Table 3 shows a comparative study of the shapes of spleens. The other forms like bilobed, trilobed, heart shaped, 
cone, tent, orange peel, foot shaped, fork shaped and lobulated spleens were not reported by previous authors as far as our knowledge is concerned regarding this aspect. All our studies showed the most common form is wedge shaped and oval shaped is less common. The cone shaped, tent shaped, heart shaped, foot shaped are the uncommon forms of spleen.

Measurements of spleen are quite important for assessment of the condition of spleen because splenomegaly indicates the diseased state of the spleen. The spleen shows a wide range of variations in its measurements. In our study we experienced difficulty in taking measurements of certain forms like irregular, trilobed, cone shaped, tent shaped spleens etc.

To assess the splenomegaly measurements are important. If length of spleen was more than $16 \mathrm{~cm}$ it is considered as enlarged. The parameters of spleen in the present study correlated well with both in vitro \& in vivo studies conducted by other authors as shown in table no-4.

The thickness of spleen in present study was slightly less than the thickness observed in 2 DUS (2 D ultrasonography) \& 3 DUS (3-dimensional ultrasonography) findings; this may be due to volume of blood circulating through spleen in living subjects.

The notches indicate the incomplete fusion between lobules of splenic tissue. The lobules are the splenic masses present between the notches. The spleen develops by fusion of aggregation of mesenchymal cells in the dorsal mesogastrium forming lobulated spleen. The lobules fuse to form a uniform structure before birth.

In the present study some spleens show more than one notch, 1-3 lobules and also fissures on the diaphragmatic and visceral surface. These were not common morphological features of spleen. This information was important for the surgeons, radiologists and anatomists. These features may mimic the injuries or new growths of organ during radiological investigations. The notches of the spleens found in the present study were compared with the findings of previous authors are shown in table no-5.

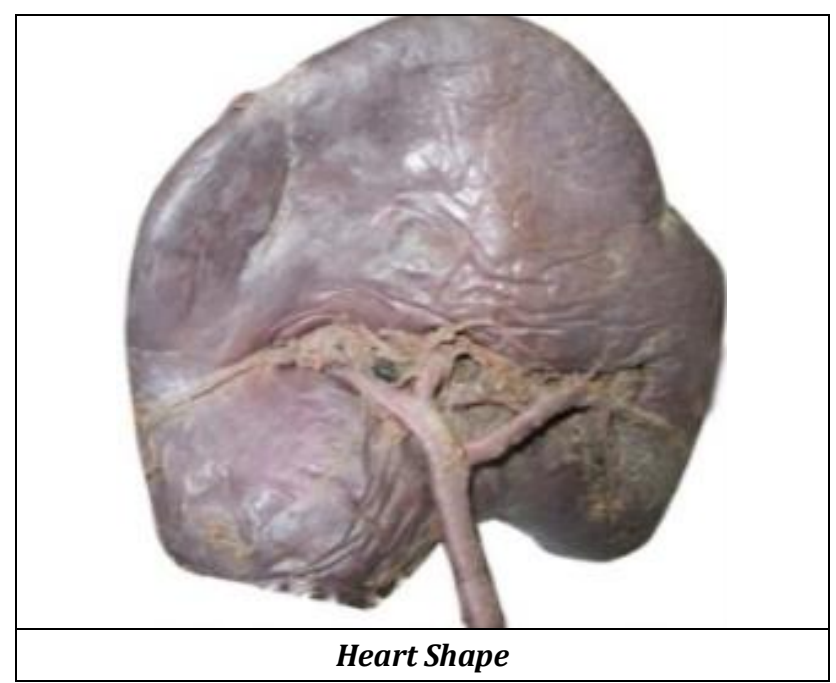

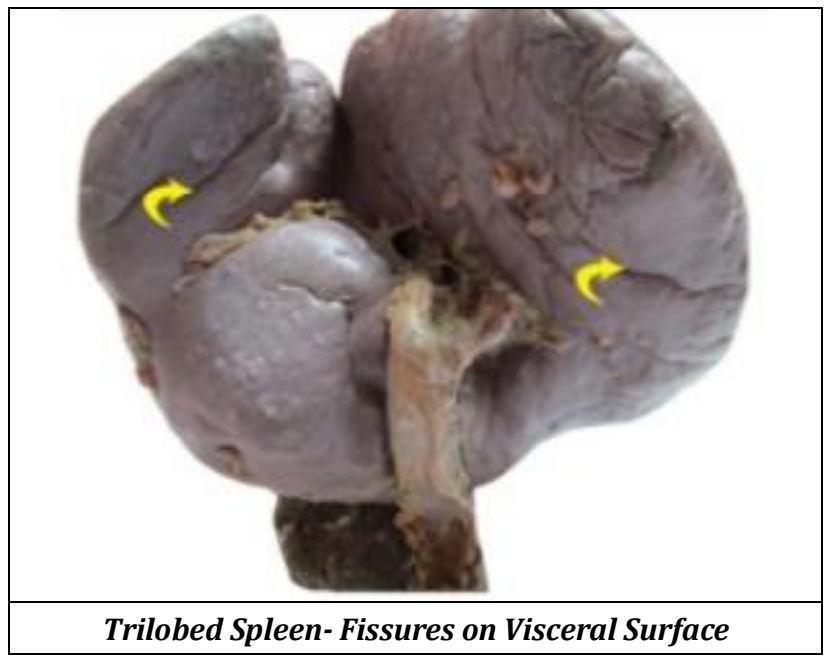
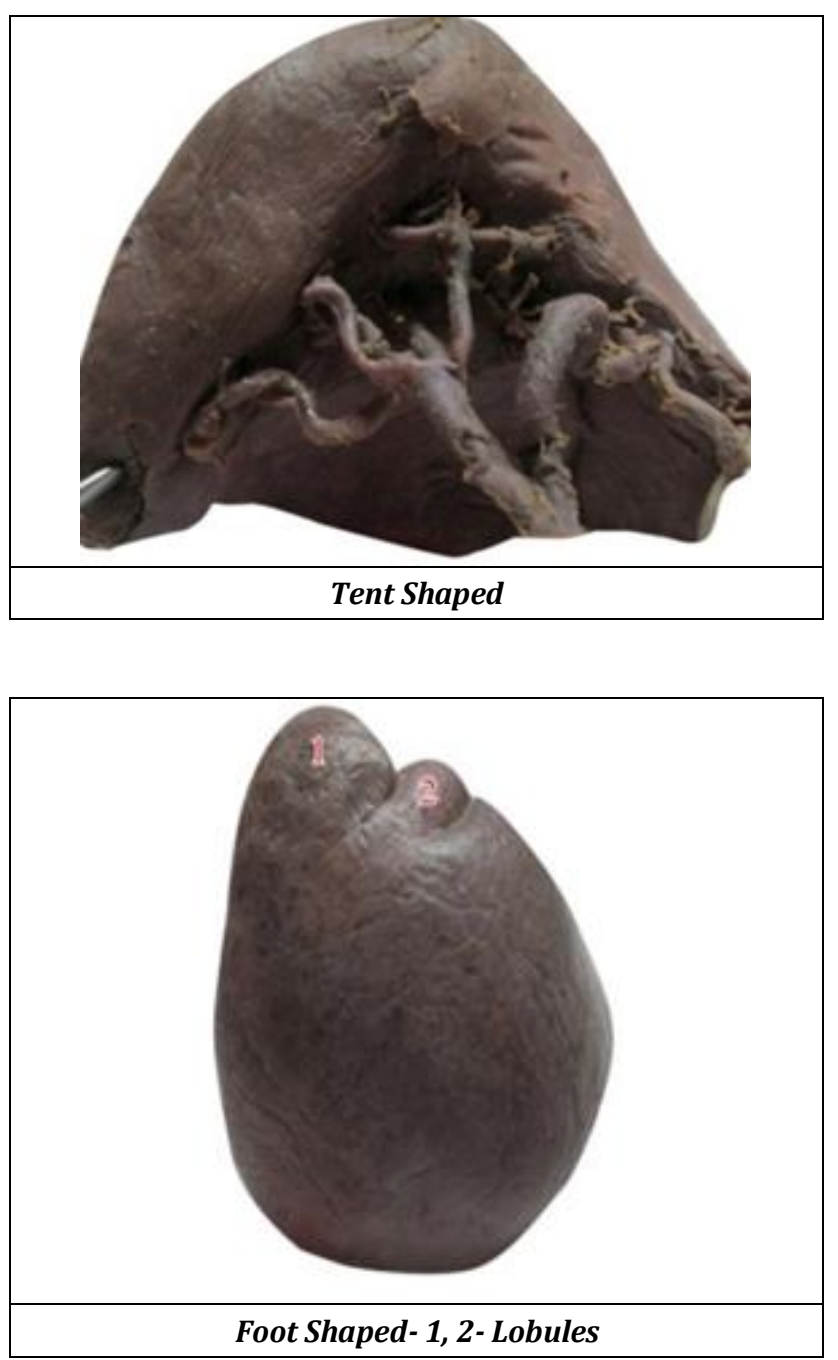


\begin{tabular}{|c|c|c|c|c|c|}
\hline Author & Wedge & Triangular & Tetrahedral & Irregular & Oval \\
\hline Michels & $44 \%$ & $14 \%$ & $42 \%$ & - & - \\
\hline Prasanth et al & $61.26 \%$ & $12.61 \%$ & $21.62 \%$ & $0.90 \%$ & $3.6 \%$ \\
\hline SRS Setty & $40 \%$ & $32 \%$ & $20 \%$ & - & $8 \%$ \\
\hline Present study & $31.66 \%$ & $11.6 \%$ & $8.3 \%$ & $8.3 \%$ & $5 \%$ \\
\hline \multicolumn{7}{|r|}{ Table 3: Shapes-Comparative Study } \\
\hline
\end{tabular}

\begin{tabular}{|c|c|c|c|c|c|c|c|c|c|c|c|c|c|}
\hline & & \multicolumn{3}{|c|}{ Length } & \multicolumn{3}{|c|}{ Breadth } & \multicolumn{3}{|c|}{ Thickness } & \multicolumn{3}{|c|}{ Weight } \\
\hline & & $\begin{array}{l}\text { Max } \\
(\mathrm{cm})\end{array}$ & $\begin{array}{c}\text { Min } \\
(\mathbf{c m})\end{array}$ & $\begin{array}{l}\text { Aver- } \\
\text { age } \\
\text { (cm) }\end{array}$ & $\begin{array}{l}\text { Max } \\
(\mathrm{cm})\end{array}$ & $\begin{array}{l}\text { Min } \\
(\mathbf{c m})\end{array}$ & $\begin{array}{l}\text { Ave } \\
\text { rage } \\
(\mathrm{cm}) \\
\end{array}$ & $\begin{array}{l}\text { Max } \\
(\mathrm{cm})\end{array}$ & $\begin{array}{l}\text { Min } \\
(\mathbf{c m})\end{array}$ & $\begin{array}{c}\text { Average } \\
(\mathrm{cm})\end{array}$ & $\begin{array}{l}\text { Max } \\
\text { (gm) }\end{array}$ & $\begin{array}{c}\text { Min } \\
\text { (gm) }\end{array}$ & $\begin{array}{l}\text { Aver- } \\
\text { age } \\
\text { (gm) }\end{array}$ \\
\hline \multicolumn{2}{|c|}{$\begin{array}{c}\text { Prasanth Nashiket } \\
\text { Chaware et al }\end{array}$} & 13 & 5 & 9.66 & 9.5 & 3.5 & 6.22 & 5.5 & 1.5 & 3.06 & 300 & 80 & 145.76 \\
\hline \multicolumn{2}{|c|}{ SRS Setty et al } & 15.5 & 7.5 & 10.15 & 12.5 & 4.5 & 8.3 & 6 & 2 & 3.96 & 325 & 30 & 138.4 \\
\hline \multicolumn{2}{|c|}{$\begin{array}{c}\text { Rayhanka et al } \\
\text { (50-69 yrs) }\end{array}$} & 11.4 & 8.3 & $\begin{array}{c}9.73 \\
+1.16 \\
\end{array}$ & 7.8 & 3.3 & $\begin{array}{c}5.53 \\
+1.73 \\
\end{array}$ & 5.10 & 1.20 & $2.23+1.32$ & - & - & - \\
\hline \multicolumn{2}{|c|}{ Michels } & - & - & 11 & - & - & 7 & - & - & 3 & - & - & - \\
\hline \multicolumn{2}{|c|}{ Gray's } & - & - & 12 & - & - & 7 & - & - & 3 & - & - & $82-150$ \\
\hline \multirow{2}{*}{$\begin{array}{c}\text { Iris } \\
\text { Deodo- } \\
\text { rico }\end{array}$} & $\begin{array}{c}2 \\
\text { DUS }\end{array}$ & 12.36 & 5.96 & 9.11 & 13.03 & 6.41 & 9.55 & 6.73 & 2.59 & 4.09 & - & - & - \\
\hline & 3 DUS & 12.20 & 5.92 & 8.84 & 12.10 & 5.59 & 8.55 & 6.34 & 2.38 & 4.01 & - & - & - \\
\hline \multicolumn{2}{|c|}{ Present study } & 15 & 6 & 9.82 & 11.5 & 4.5 & 8.24 & 3.5 & 1.5 & 2.85 & 180 & 70 & 131 \\
\hline
\end{tabular}

\begin{tabular}{|c|c|c|c|c|}
\hline Author & $\begin{array}{c}\text { Absence of } \\
\text { Notches }\end{array}$ & $\begin{array}{c}\text { Notches on Superior } \\
\text { Border }\end{array}$ & $\begin{array}{c}\text { Notches on Inferior } \\
\text { Border }\end{array}$ & $\begin{array}{c}\text { Variations in the Number } \\
\text { of Notches }\end{array}$ \\
\hline Prasanth et al & $0.9 \%$ & $74.76 \%$ & $24.32 \%$ & $0-6$ \\
\hline SRS Setty et al & $16 \%$ & $64 \%$ & $20 \%$ & $0-5$ \\
\hline Das et al & - & $98 \%$ & $2 \%$ & $2-4$ \\
\hline Hussein et al & - & $59.3 \%$ & $12.5 \%$ & -7 \\
\hline Nayak. B. S & - & $50 \%$ & - & - \\
\hline Skandalakis et al & - & $78.6 \%$ & - & - \\
\hline Soyluolu et al & - & $70 \%$ & - & - \\
\hline Ungor et al & - & $95 \%$ & Nil & $0-3$ \\
\hline Present study & $3.4 \%$ & $96.6 \%-$ & \\
\hline
\end{tabular}

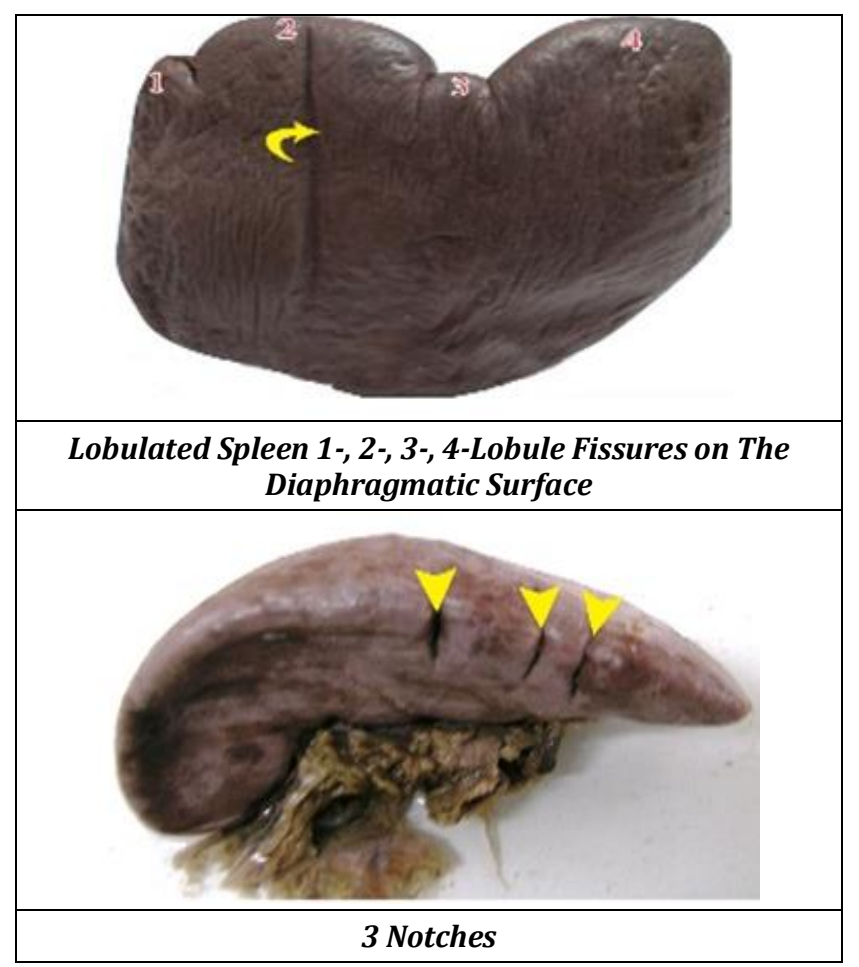

In the present study the fissures were noticed in $6.6 \%$ on the diaphragmatic surface \& $5 \%$ on the visceral surface. Ungor Bahady et al reported fissures in $7.8 \%$ of spleens. Srijit Das et al reported fissures on the diaphragmatic surface in 2 $\%$ of specimens, whereas in the present study fissures were seen in $11.6 \%$ of spleens. In our opinion the fissures were formed due incomplete fusion of splenic tissues over the diaphragmatic and visceral surfaces of the spleen. The reason for bilobed \& trilobed spleens may be due to incomplete fusion of large masses of splenic tissue.

Accessory spleens were one or more splenic masses which develop in one of the peritoneal folds near the hilum of spleen. They occur in $10 \%$ of people and about $1 \mathrm{~cm}$ in diameter.[6] The accessory spleens were usually isolated but can be connected to the spleen by thin bands of splenic tissue.[5] Halpert and Eaton reported the size of accessory spleens varied from $0.2-3 \mathrm{~cm}$ in diameter and showed $10 \%$ occurrence. Curtis \& Movitz found accessory spleens in 31.4 $\%$ out of 178 patients. Souparis et al_studied presence of retroperitoneal accessory spleens and concluded they mimic retroperitoneal tumors. Curtis \& Movitz pointed that in case of splenectomy for haemolytic icterus, leukaemia accessory spleens must be removed along with spleen proper for better results. 
In the present study two accessory spleens were observed out of 60 specimens [3.33\%]. One accessory spleen was pea shaped \& pea sized present near the hilum measuring $1 \mathrm{~cm}$ in diameter. The second accessory spleen was large $3 \mathrm{~cm}$ in diameter located on the visceral surface of spleen in a deep depression and connected to main spleen by a bridge of splenic tissue and having its own blood supply from a branch of splenic artery. Findings of accessory spleens in present study were compared to the accessory spleens reported by various authors were shown in table no- 6 .

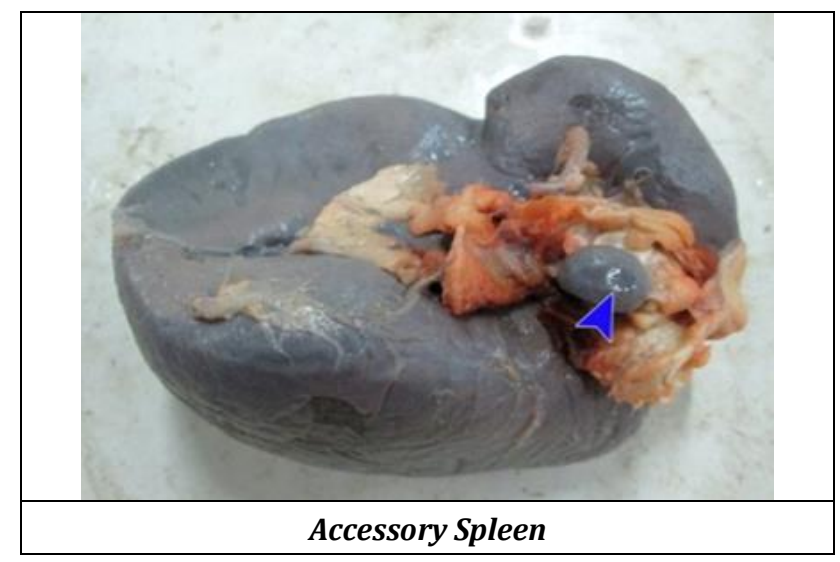

\begin{tabular}{|c|c|c|}
\hline Author & Percentage & Size \\
\hline Moor \& Persaud $^{7}$ & $10 \%$ & $1 \mathrm{~cm}$ in diameter \\
\hline Halpert\& Eaton & $10 \%$ & $0.2-3 \mathrm{~cm}$ in diameter \\
\hline Curtis \&Movitz & $31.4 \%$ & - \\
\hline Rayhanka et al & $14.3 \%$ & - \\
\hline Weiand \& Mangold & $10-15 \%$ & - \\
\hline Prasanth et al & $4.5 \%$ & - \\
\hline Present study & $3.33 \%$ & $1 \mathrm{~cm}-3 \mathrm{~cm}$ in diameter \\
\hline \multicolumn{2}{|c|}{ Table 6. Percentage of Accessory Spleens } \\
\hline
\end{tabular}

\section{CONCLUSIONS}

Spleen is very essential to lead a healthy life which was evident in patients who had undergone splenectomy. The measurements of spleen is necessary to assess conditions like splenomegaly and to preserve at least $1 / 4^{\text {th }}$ of the splenic tissue in partial splenectomy cases to retain the normal function of the spleen. The knowledge of different shapes of the spleen, presence of notches in unusual sites, occasional presence of fissures on the surfaces, lobed \& lobulated spleens and accessory spleens is important for physicians, surgeons, radiologists and anatomists.

\section{REFERENCES}

[1] King H, Shumacker HB. Splenic studies. I. Susceptibility to infection after splenectomy performed in infancy Ann Surg 1952;136(2):239-42.

[2] Singer DB. Post splenectomy sepsis. Perspect Pediatr Pathol 1973;1:285-311.

[3] DicKerman JD. Bacterial infection and the asplenic host: a review. J Trauma 1976;16(8):662-8.

[4] Kumar V, Abbas AK, Fausto N, et al. Robbins and Cotran pathologic basis of disease. $8^{\text {th }}$ edn. New Delhi: Saunders Elsevier 2010:632-5.

[5] Standring S. Gray's anatomy-The Anatomical basis of the clinical practice. 39th edn. Edinburg: Elsevier Churchill Livingstone 2006:1239-44.

[6] Moore KL, Persaud TVN. The developing human: clinically oriented embryology. 7th edn. Edinburg: Elsievier Churchill Livingstone 2005: p. 266.

[7] Hollinshead WH. Anatomy for surgeons: the head and neck. $3^{\text {rd }}$ edn. Vol 2. New York: Harper and Row 1982:442-6.

[8] Varga I, Galfiova P, Adamkov M, et al. Congenital anomalies of the spleen from an embryological point of view. Med Sci Monit 2009;15(12):RA269-76.

[9] Lamb PM, Lund A, Kanagasabay RR, et al. Spleen size: how well do linear ultrasound measurements correlate with three-dimensional CT volume assessments? Br J Radiol 2002;75(895):573-7.

[10] Rayhan KA, Ara S, Nurunnabi ASM, et al. Morphometric study of the post-mortem human spleen. J Dhaka Med Coll 2011;20(1):32-6. 